\title{
POLISH-GERMAN STRUGGLE FOR INFLUENCE IN UPPER SILESIA DURING THE SANITATION PERIOD (1926-1939)
}

In 1922, by decision of the Council of Ambassadors of the great powers, part of the lands of Upper Silesia was incorporated into the Polish State. Germany has never accepted these provisions. Throughout the interwar period, Upper Silesia was a space of Polish-German competition for political, economic, social and cultural influence. This region was important for the economy of The Second Republic of Poland. The Silesian Voivode Michał Grażyński, associated with the sanitation camp, conducted a repolonization policy. Upper Silesia was particularly vulnerable to the hostile activities of foreign intelligence, especially the German Abwehr. German intelligence involved representatives of the German minority living in the Polish part of Upper Silesia. This was a major challenge for Polish special services. The protection of the counter-intelligence service of Upper Silesia was a priority task of the special services of the Second Republic of Poland. The article uses a method of analysis of archival sources and a critical analysis of the literature of the subject. Archival sources and scientific publications were used in the work.

Keywords: security policy, Upper Silesia, Silesian sanation, counterintelligence of the Second Republic of Poland, German minority.

\section{INTRODUCTION}

On October 20,1921, the Council of Ambassadors of the Great Powers issued a decision on the division of Upper Silesia between Poland and Germany.16 July 1922 in Katowice, a ceremony was held for the unification of Upper Silesia with Poland, during which a symbolic act of integration into the Republic of Poland was signed, which for several hundred years remained outside its territories. A border line between the two countries has been set up and a number of administrative, communication and economic issues have been addressed (Oświadczenie rządowe z dnia 23 maja 1922 r. w sprawie podziału Górnego Śląska...). The Polish and German sides are committed to respecting the rights of national minorities. Germany, however, has never accepted the provisions of the Treaty of Versailles. Already in the first years after the war, they began the process of consolidating the German population living outside the country. This posed a great danger of changing the established status quo in Europe. Throughout the interwar period, Upper Silesia

\footnotetext{
${ }^{1}$ Malwina Siewier, PhD, Department of Security Sciences, Faculty of Social Sciences, Jan Dlugosz University, ul. Waszyngtona 4/8, 42-200 Częstochowa; e-mail: malwina.siewier@gmail.com. ORCID: 0000-0001-6734-0745.
} 
remained a space of Polish-German competition for political, economic, social and cultural influence.

The May coup in 1926 transformed the political scene of interwar Poland. Józef Piłsudski and his supporters took power. They called for a sanitation programme, that is, the healing of moral socio-political and systemic relations in the state. Reform has been launched from parliamentary democracy to authoritarian rule. Józef Piłsudski played a special role in this process (Długajczyk, 1986). It was envisaged to introduce a form of state governance that provided for the smooth implementation of the strategic objectives of the Second Republic, including the maintenance of internal stabilisation (Paruch, 2009). This event also had negative consequences. The Polish armed forces were used for fratricidal fighting, which was de facto a political battle for power in the state. Many soldiers, as well as civilians, were killed. In addition, the image of the Polish Army, as an apolitical force defending the country's independence and sovereignty, was undermined (Wiśniewska i Wyszczelski, 2009).

In 1926, the socio-political situation in the Silesian Voivodeship was complicated. The Union for the Defense of the Western Borderlands and the Union of Silesian Insurgents demanded the resignation of The Voivode Mieczysław Bilski, accusing him of having no effect in the polonization of Upper Silesia. The political struggles that led to the consolidation of Polish society have had a negative impact. Internal divisions and conflicts were exploited by the German minority. It affected the part of the population of the Silesian voivodeship, which did not have a national identity (Gerlich, 1998). In January this year, Voivode Bilski resigned. However, it was not accepted by the Polish Government. In April, the delegates of the Union of Silesian Insurgents - Michał Grażyński, Rudolf Kornke, Antoni Olszowski and Alfons Zgrzebniok went to Sulejówek. Marshal Józef Piłsudski expressed his support for the presented demands of the Polonization policy of Upper Silesia. The dominant position among the delegates was Michał Grażyński, who was a recognized leader in the Silesian sanitation camp. He supported the May upheaval and the actions Pilsudski-ite, which influenced his further political career. August 28, 1926 President Ignacy Mościcki appointed Michał Grażyński as the governor of Silesia. As the leader of the Silesian Sanation, he established a pro-government political camp, operating within the framework of the National-Christian Labour Union, the Silesian equivalent of the Non-Partisan Bloc of Cooperation with the Government. He was a member of the sanatorium left, since May 1926, concentrated in the Union for the Repair of the Republic of Poland (Nowak, 2014). Grażyński was a supporter of the policy of "equal steps", the main objective of which was to eliminate the disparities that existed in the position of the Polish and German minorities and the gradual repolonization of Upper Silesia, which in the context of the existing conditions was a difficult task (Drozdowski, 1991); (Łączewski, 2000).

One of the factors influencing the situation in the Silesian voivodeship was German revisionism, systematically implemented since the mid-1930s. In January 1933, Adolf Hitler became Chancellor of Germany, leading the National Socialist Movement. It has, in general, created a programme to accelerate arms and conquer Europe. An important role in this regard was assigned to Abwehr. Division of the II General Staff (since 1928 Main) of the Polish Army dealt with the identification and fight of German espionage. Abwehr's most important task was to get to know polish defensive preparations. The German secret services used the German minority to a large extent for intelligence activities. Cooperated with social, cultural, sports associations, banks and scientific institutions operating on polish territory (Ćwięk, 2001). 
Upper Silesia was particularly vulnerable to the hostile activities of Abwehr. The protection of the counter-intelligence service of the region was an important task of the Polish special services. The events at home and around the world, the May coup in 1926, the economic crisis of 1929, the political crisis in Germany in 1933, which ended with Hitler taking power, did not interrupt the continuity of German intelligence activities against Poland. Since 1933, the spy operations of the Secret Service of the Third Reich have been carried out on a much larger scale, reaching the highest level before the outbreak of World War II (Kozaczuk, 1977). During this difficult period, the counter-intelligence facilities of The Division II, as well as supporting them, other security authorities in Upper Silesia, were forced to make an increased effort to ensure the safety and interests of the Polish state.

The research objective of this article is to present the Polish-German competition for influence in Upper Silesia, in the context of existing conditions. The security threat in the area has been characterised by German intelligence. The role of the German minority in the revisionist policy of the Weimar Republic and the Third Reich was highlighted. In addition, the harmful activities of the so-called 5th column in Upper Silesia in the last months before the outbreak of the war in 1939.

When considering research problems, the method of analysis of archival sources and critical analysis of the literature of the subject were used. Source material and scientific papers on certain aspects of the issue have been used.

\section{THE ROLE OF THE GERMAN MINORITY}

The national situation in the Silesian Voivodeship was shaped by three factors, the first was the conferral of autonomy to the Silesian voivodeship, the second - the adoption of the Upper Silesian Geneva Convention, the third - the signing of 28 June 1919. treaty on the protection of national minorities. Weimar Germany was not required to meet this condition, although national minorities, including the polish minority, lived on their territory. This was contrary to the principle of equality of state before international law. It also meant that Poland's internal affairs would be dealt with at an international forum in Geneva. This unfavourable situation for the Polish side was often exploited by The Germans, referring to the complaint procedure of the Upper Silesian Geneva Convention, trivial matters giving rise to serious abuses, while creating an atmosphere of anxiety and insecurity of internal security. This was part of the tactics adopted by the German authorities to deliberately and systematically discredit the Polish State on the international stage (Łaczewski, 2000). Despite the obligations contained in the Upper Silesian Convention, the situation of the Polish and German minorities was different. Poles living in Opole Silesia had to fight for basic rights to children in Polish schools, to have a Polish-speaking press and trade unions. The German minority in this area was able to function fairly freely. Germans living in the Polish part of Upper Silesia often engaged in social, political, economic and cultural life (APK, PWŚ, sygn. 196, Pismo Miej. i Pow. Kom. PWŚ do kierowników Komisariatów i Posterunków PWŚ powiatu katowickiego, dot. szkół niemieckich, z 12 VI 1926 r., k. 1; APK, PWŚ, sygn. 130, Sprawozdanie miesięczne ze stycznia 1927 r., z 8 II 1927 r., k. 34).

A large part of the Upper Silesian industry belonged to German investors and entrepreneurs, which resulted in the Germans exerting economic pressure on the authorities of the Polish State. In this regard too, a strong and well-organised German minority was an important link in economic domination. the Weimar Republic, and since 1933 the Third Reich has been keen to maintain influence in the region. Various forms of support were 
used for compatriots living in "lost areas". Under the provisions of the Treaty of Versailles, Germany was not allowed to conduct offensive intelligence. However, despite the imposed restrictions, they efficiently organized special actions against Poland.The functions of camouflaged intermediaries were performed by seemingly private and non-government-related minority organizations. Very often, in addition to achieving their statutory objectives, they were assigned intelligence tasks. They provided important information on strategic and military importance to the German services. This phenomenon was widespread and had a very negative impact on the security of the Second Republic (Ćwięk, 1999).

Deutscher Volksbund für Polnisch-Schlesien (Volksbund - VB, The German People's Union for Polish Silesia) was considered a political representation of the German minority. His longtime leader was Otto Ulitz. Volksbund played an important role in conducting espionage activities against Poland. He was the political, military and economic intelligence body of the German Consulate in Katowice. He maintained close contact with the Political Department of the Upper Silesian Province In Opole and the border police station in Opole. He cooperated with the Abwehrstelle-Schlesien intelligence service in Wrocław and in Opole and Bytom. A special information facility was set up in the Main Board of the Union to oversee the activities of these cells in peripheral organizations, which in turn were involved in recruiting trustees for intelligence work. Volksbund sent to the German authorities reports on the activities of the party, reports on the internal situation in the Polish state, messages on the defence of the Republic of Poland (APK, PWŚ, sygn. 243, Pismo 23 Dywizji Piechoty do Śląskiego Urzędu Policji Politycznej w Katowicach, z 26 V 1925 r., k. 7; APK, PWŚ, sygn. 243, Pismo Miej. i Pow. Kom. PWŚ do Śląskiego Urzędu Policji Politycznej w Katowicach, z 11 VII 1925 r., k. 9). He participated largely in propaganda activities against Poland. In December 1930, the union filed a complaint with the League of Nations, citing as many as 255 acts of terror allegedly experienced by the German minority in Upper Silesia by the Union of Silesian Insurgents. Participation in these incidents was also attributed to officers of the Silesian Voivodeship Police, who were accused of using threats and blackmail and unlawfully conducting house searches (APK, PWŚ, sygn. 215, Wycinek z prasy, br., k. 222); (APK, PWŚ, sygn. 215, Pismo Pow. Kom. PWŚ w Tarnowskich Górach do GK PWŚ w Katowicach, z 1VI 1927 r., k. 223).

The governor of Grażyński, who took the floor on the matter, was responsible for the alleged persecution. In an interview with foreign journalists, he noted that the main cause of concern is the desire of the leaders of the German minority and the authorities in Berlin to change the decision on the division of Upper Silesia and the inclusion of the region in Germany. The voivode believed that, according to the Polish state ration, the privileges of the German minority should be reduced and its economic advantage in Silesia should be reduced. Felix Calonder, President of the Polish-German Mixed Committee in Katowice, strongly supported the Germans without listening to the arguments of the Polish side.On 5 and 6 December 1930, in an interview with The Minister of Foreign Affairs, August Zaleski, he demanded the resignation of Michal Grażyński from his office and the official condemnation by the Polish authorities of the acts of terror in the Silesian voivodeship. The Polish Government has not agreed to such a solution. It was important to continuate the process of integration of Upper Silesia into the Republic of Poland (APK, PWŚ, sygn. 247, „Polska Zachodnia” z 3 IV 1931 r., k. 171). Over time, Nazi ideology became increasingly popular among the German minority living in the region. The Germans were mostly seducedby Hitler's national socialist vision of The Great Germany (Großdeutschland). 
Jungdeutsche Partei (JDP) was the second Nazi party in the Silesian voivodeship. After the transformation in 1932, the JDP fought for the political support of the German minority in Upper Silesia (APK, PWŚ, sygn. 202, Raport przygotowany dla Departamentu I Politycznego MSW w Warszawie, dot. ruchu hitlerowskiego w województwie śląskim, z 1 XII 1932 r., k. 105-108). Jungdeutsche Partei's activities consisted of consistent and intensive pushing of the Nazi programme and the indoctrination of the population in Poland (APK, PWŚ, sygn. 209, Doniesienie w sprawie członków „Jungdeutsche Partei” i „Deutsche Arbeiterpartei”, z 1932 r., k. 3).

Adolf Hitler called for the merging of German irredents outside Germany. At a confidential meeting in Berlin in the spring of 1934, he said to the current leaders of the German minority:

"You should transform yourself into a combat unit (...) Therefore, you cannot act at your discretion, but listen to commands. What seems beneficial to you, from a higher point of view, can be harmful. You will not judge what is within your scope of action. That is why I demand from you, above all, blind obedience" (Potocki, 1984).

The JDP almost completely became like the Nationalsozialistische Deutsche Arbeiterpartei (NSDAP, The National Socialist German Workers' Party) (APK, PWŚ, sygn. 212, Pismo Wydziału Śledczego Miej. i Pow. Kom. PWŚ w Katowicach do Prokuratury Sądu Okręgowego w Katowicach, z 11 VII 1936 r., k. 236-237).

The National Sozialistische Deutsche Arbeiter Bewegung (NSDAB, National Socialist German Workers' Movement) also ran anti-Polish activity in the Silesian Voivodeship. Its main purpose was to detach the Polish part of Upper Silesia from the Republic and join it to Germany. It was planned that this would happen through a political and armed speech against Poland. An intelligence service was set up at the NSDAB to gather information about the political activities of Polish and German organizations in Poland. She was also involved in the reconnaissance of police dislocation, border guards and the development of the activities of semi-military organizations (APK, PWŚ, sygn. 207, Pismo Miej. Kom. PWŚ w Chorzowie do GK PWŚ w Katowicach, z 18 III 1936 r., k. 180-183).

The German organisation Bund Deutscher Osten (BDO, Union of the German East) was involved in the process of depolonization in Opole Silesia and the conduct of anti-Polish propaganda activities among German society. She called for an armed speech against Poland and the seizure of Upper Silesia by German military troops (APK, PWŚ, sygn. 406, Orzeczenie Ekspozytury nr IV Oddziału II SG w Katowicach, z 21 VI 1939 r., k. 9-10).

The Gewerkschaft Deutscher Arbeiter (GDA, German Workers' Union) implemented the political ordinances of the Deutsche Arbeitsfront (DAF) operating under the aegis of the Nazi Party. GDA recruited its members from among German workers. The union apparently carried out legal activities, pursuing the basic statutory objectives. However, during board meetings and meetings in a narrow, trusted group, decisions were taken of the anti-Polish nature of the (APK, PWŚ, sygn. 388, Opinia Miej. Kom. PWŚ w Chorzowie o członkach zarządu GDA, 14 III 1939 r. k. 247-248). Jobseekers in Germany were encouraged to bring military books to guarantee some work. In fact, these documents were material for analysis for the German intelligence services.Deserters from polish army units were willingly accepted, which were meticulously recorded in the register. GDA members were involved in collecting a variety of information about job applicants, which they provided to German 
intelligence officers (APK, PWŚ, sygn. 406, Orzeczenie Ekspozytury nr IV Oddziału II SG w Katowicach..., k. 10-11).

The hostile attitude of The Voivode Michał Grażyński to Nazi ideology was known to the Polish authorities. On May 3, 1935, Foreign Minister Józef Beck and Deputy Minister of this Ministry Jan Szembek refused to organize a demonstration in the capital of 5,000 Silesian insurgents on the anniversary of the outbreak of the third uprising. The ban was issued at the last minute under pressure from the German government. Minister Szembek accused the Silesian Voivodeship of reporting "territorial pretensions against the Reich" and "violent anti-German attitude". He was of the opinion that Grażyński's policy of "strong hand" towards the German minority is detrimental to Poland, as it further complicates the already poor relations on the Warsaw-Berlin line (Ajnenkiel, 1980).

In 1937, the Upper Silesian Convention of Geneva ceased to apply. In Opole Silesia there was an aggressive policy of inflicting Polish skies. Josef Wagner, Nazi superpresident of the Upper Silesian province, took an extremely anti-Polish course. He believed that all historical evidence of Upper Silesia should be destroyed. According to his policy, Polish inscriptions on tombstones, cemeteries, monuments, churches were abolished, polish journalists were stripped of their work, the lives of Polish families were monitored. The names of the inhabitants and the names of the localities were changed administratively (APK, PWŚ, sygn. 172, Pismo Pow. Kom. PWŚ w Lublińcu do GK PWŚ w Katowicach, z 23 XII 1925 r., k.377; Łączewski, 2000).

Voivode Michał Grażyński saw the danger of expansion of Nazi influence in Upper Silesia. He tried to stop her, but he did not have the right freedom of action. The continuing intervention of the Minister of Foreign Affairs, demanding that the governor maintain a proper relationship with Germany, greatly limited his ability to act appropriately against Nazi groups. The authorities of the Second Republic at all costs tried to prevent the deterioration of Polish-German relations, considering that in this way they would ensure the security of the state.

\section{COUNTERINTELLIGENCE ACTIVITY OF THE SECOND DEPARTMENT OF THE GENERAL STAFF OF THE POLISH ARMY IN UPPER SILESIA}

Abwehr was established in January 1921.The name was derived from the headquarters of the Abwehrgruppe der Reichswehr, a convent in the Department of Statistics of the Military Office. This office was the General Staff of the Reichswehr in the Reichswehrministerium. Abwehr included two papers: "Ost" and "West", under which the departments of three divisions: intelligence, radio intelligence and ciphers, and counterintelligence. It was to fight foreign espionage, sabotage, protect the military from subversive agitation and assassination attempts. In addition to counterintelligence tasks, Abwehra was involved in offensive intelligence against Poland, among others. Intelligence tasks on its territory carried out as many as five (out of eight) field displays (Abwehrstellen). These were the I - Abwehrstelle in Królewiec, II - in Szczecin, III - in Berlin (with a branch in Frankfurt (Oder), IV - in Dresden, VIII - in Wroclaw (Ćwięk, 2001). The Polish-German struggle on the secret front continued throughout the interwar period, albeit with varying intensity. Abwehr's activities in the Silesian Voivodeship and its fight by the Polish counterintelligence authorities constitute an important part of Polish-German relations.

Active intelligence activity in the area of Upper Silesia was carried out by the Abwehrstelle-Schlesien facility. It covered the scope of western provinces, especially 
Silesian, as well as central and south-eastern ones. Abwehrstelle-Schlesien was established in 1921 at the command of the 2nd Cavalry Division in Wrocław. Experienced intelligence officers from the Polish-German struggles for Upper Silesia (1919-1921) worked there. Since 1933 in Germany, an army expansion programme was launched, which also meant an increase in the size and importance of Abwehr. During this period, German intelligence services were primarily interested in issues relating to the armed forces and industry of the Second Republic.They conducted recognition in the areas of organization, training, armaments, supply, combat and moral value of soldiers, industrial innovation, manufacturing matters, number of employees (Ćwięk, 1998).

Since 1928 Polish political and military circles began to see the need to expand the measures to secure the western border of the Republic, on the Silesian section. Operational studies conducted in Upper Silesia have made it clear how important this region is to the defence of the whole country. The analyses showed that in the event of armed conflict, the demand for Upper Silesian coal would be 80 percent. It was found that during the mobilization and war, the production of metallurgical iron must be 100 percent based on Upper Silesian coke, which was also necessary for the chemical industry in other parts of Poland. In addition, the semi-finished products of the Upper Silesian metallurgical industry were highly important. In the following years, efforts were made to solve the problem related to the nationality of the workers of the mining and metallurgical industry, taking further steps towards its polonization (Wanatowicz, 1997).

Due to the special place of Upper Silesia in the defence system of the Second Republic, it was exposed to intensive and systematic penetration of the German special services. The expanded apparatus of German intelligence, dragged into the orbit of all pro-German organizations, after 1933. pro-Nazi, out-of-bounds. Lively border traffic, good communication links, intelligence involvement of representatives of the German minority and the passivity of certain groups of Poles, financially and economically linked to German industry, fostered the espionage activities of Germany (Ćwięk, 2006). Ensuring counterintelligence protection in Upper Silesia was an important task of the services of the Second Republic.

Tasks in this regard were carried out by employees of the Independent Information Office (IIO) of the Corps District Command No V in Krakow. IIO facility, located at 23. the Infantry Division in Katowice conducted operational activities in Upper Silesia.In addition to combating the influence of foreign intelligence and the diversion of the enemy, the protection of military secrets and the security of military institutions and the recognition of the political, social and national situation were addressed (IPN Ka, sygn. 063/84 t. 1, Charakterystyka kontrwywiadowcza województwa katowickiego, k. 77; Misiuk, 2016).

As part of Department II a. offensive intelligence against Germany was conducted by the Department of the 4th Division of the General Staff in Krakow (from 1930 in Katowice). It covered the entire area of Silesia. Due to the specificity of the region, the facility had to actively participate in counter-intelligence protection. Branch 4 , operating in difficult conditions, successfully performed the tasks of observing the intelligence field, which was particularly important in the situation of persistent tension in Polish-German relations (Kozaczuk, 1977). Officer's Post No. 2 in Katowice performed counter-intelligence tasks in the area of Upper Silesia and the surrounding area (IPN Ka, sygn. 063/84 t. 1, Charakterystyka kontrwywiadowcza..., k. 85-86). Interesting materials in the scope of intelligence reconnaissance of the western neighbor were also in the 3rd Department of the Main Staff in Poznań (from 1930 in Bydgoszcz). It conducted intelligence activities in the 
area of the Free City of Gdansk, East Prussia, Western Pomerania and in the border area north of the Warta and the Poznań-Berlin railway line. The activities of the offensive intelligence exhibition were correlated with counterintelligence activities (Ćwięk, 2009).

The organizational and economic superiority of the German minority in Poland, compared to the Polish minority in Germany, as well as the cautious policies of Minister Józef Beck, gave Germany an advantage in the economic interview. The authorities responsible for ensuring security in Poland have increasingly communicated the problem related to the activities of trade and industrial intelligence institutions in the country. It was estimated that many intelligence agencies, both private and state-owned, collected information about Poland's war industry, which was meticulously used by German intelligence. It was important to secure the state against further leakage of economic data of strategic importance for national security (Pepłoński, 2002).

The problem with the activity of commercial intelligence, which is a source of information about the economy of the Second Republic for foreign countries, was particularly highlighted in Upper Silesia. For example, in 1927, Department No. 4 of the Second Division of the General Staff in Krakow sent a notification to the Silesian Political Police Office in Katowice about the foreign and local interview conducted, as a result of which it was found that companies: Auskunftei Schimmelpfennig (Schimmelpfenni (Credit Agency Schimmelpfennig), Deutsche Auskunftei Breslau (German Information Agency Wrocław), Auslandsabteilung des Verbandes der Vereine Creditreform Leipzig (Foreign Department of the Creditreform Leipzig Association) and Handelsauskunftei Joks - Görs Gabriel, Danzig (Trade Agency Joks - Görs - Gabriel, Gdańsk), Auskunftsstelle des Kartells der Auskunfteien Bürgel Danzig (Cartel Information Office for Credit Bureaus, Gdansk, Poland), have their counterparts in the Silesian Voivodeship. Under the guise of commercial intelligence, they conducted economic and military intelligence. They had representatives in district cities and larger towns in Upper Silesia, as well as paid agents throughout the country (APK, PWŚ, sygn. 237, Pismo Ekspozytury nr 4 Oddziału II SG w Krakowie do Śląskiego Urzędu Policji Politycznej w Katowicach, z 25 VII 1927 r., k. 841).

They provided detailed information on the functioning of the Polish State. It was found that Wrocław companies worked according to the instructions and under the direction of Abwehrstelle-Schlesien and the German political police. In addition to their commercial intelligence, they engaged in military espionage. They employed German intelligence officers to achieve these objectives. Wrocław agencies were in close contact with the superintendent of the political police, as well as the head of Abwehrstelle-Schlesien. Information on economic espionage of these companies was provided to the management of the competent security authorities and the Ministry of the Interior (APK, PWŚ, sygn. 237, Pismo Kierownika Posterunku Oficerskiego nr 2 w Katowicach, dot. szpiegostwa niemieckiego, z 1 VIII 1927 r., k. 842).

The expanded outposts of German economic intelligence against the Second Republic for many years had no equivalent on the Polish side. In December 1932, the Ministry of Industry and Trade, with the consent of the Presidium of the Council of Ministers and in consultation with the Department of the Second Main Staff, established a specialized industrial and commercial intelligence facility - the Polish Trade Information Agency (PTIA). State and local authorities were to support its activities and, if necessary, use its services (APK, PWŚ, sygn. 237, Pismo MSW do wojewodów, dot. utworzenia PAIH, z 23 II 1932 r., k. 374). PTIA was established as a seemingly private company based in Warsaw, which was in fact an unofficial outpost of the broadly understood economic intelligence of 
the Second Republic. PTIA interviewed, gave opinions and provided information about suppliers, companies and companies in contact with the military. Their loyalty to the Polish State, as well as their functioning, financial responsibility and professionalism were (Kozaczuk, 1977).

PTIA performed thematic analyzes commissioned by the Second Department of the General Staff, which were to show the impact of various industrial and commercial facilities operating on the basis of foreign capital harmful to the defense of the country. This task was performed by the "S" Department within the Agency. Its employees produced periodic studies on key industries and trade, assessing their condition in terms of the country's defence needs. Employees of the Polish special services verified the received documents. In 1937, the news was rated as "good" or "pretty good". There were also attempts to use PTIA to conduct deep intelligence in the Third Reich, especially penetrating its military industry. The materials provided by the Agency showed the scale of exploitation and influence of foreign capital in almost every segment of the Polish economy (Kozaczuk, 1977).

Polish counterintelligence facilities correctly assessed the threat posed by persons of German origin employed in the German industry. The execution of military orders often required insight into the structural elements of military equipment. The counter-intelligence authorities had data showing the links between the staff of the "Bismarck" steel works in Katowice with German intelligence. The chief executive was Robert Scherff, polish national of German nationality. The smelter produced for the polish army: cannon cores, pitchers, barrels and bearings for machine guns, plates for armored cars. This situation also affected other factories in Upper Silesia, such as the "Baildon" in Katowice, or "Bethlen-Falva" in Świętochłowice (Pepłoński, 2002).

Counter-intelligence facilities in Upper Silesia, taking into account the existing conditions, have achieved satisfactory results in the fight against the influence of German intelligence. The most effective was the Independent Information Department of the Corps V District Command and the Department of the 4th Division of the 2nd General Staff. Polish courts have sentenced them to death or long prison sentences for espionage. However, the penalties were relatively low compared to the losses suffered by the Polish State as a result of hostile activities. The great indulgence of the German minority involved in intelligence activities encouraged the creation of further secret organizations and the involvement of espionage and diversionary actions (Ćwięk, 2001).

In 1938, the Polish-German border was extended. The counter-intelligence facilities of the Second Republic were much more difficult to protect the state from the influence of German intelligence. Abwehr's facilities in Upper Silesia collected data on the system of fortifications and fortifications. In the run-up to the outbreak of the war in 1939, German military intelligence focused on recognizing Poland's defence capabilities. In Upper Silesia, 55 suspects were arrested on suspicion of espionage between March and July this year. Between 1929 and 1939, about 4,000 people were detected on the services of foreign intelligence. About two-thirds of the agents were Polish nationals of other nationalities. Between 1935 and 1938, counter-intelligence authorities revealed about 300 cases of espionage for the Third Reich (Ćwięk, 1999). Since April 1939, there have been numerous preventive arrests, due to the deterioration of Polish-German relations and the intensification of German intelligence and diversionary activities. It is difficult to accurately estimate the scale of espionage in interwar Poland. It is highly likely that up to a dozen thousand people could cooperate with interviews of foreign countries. The data contained 
in the source material indicate that the scale of espionage has increased significantly over the years. The majority of the detected crimes took place in the last years of interwar Poland (Długajczyk, 2007; Sprengel, 2014).

\section{V COLUMN BEFORE THE OUTBREAK OF WORLD WAR II}

In March 1939, a new phase in Polish-German relations began. The reason for these changes was the territorial demands made by the Third Reich against Poland. The deepening Polish-German conflict was accompanied by the propaganda of Joseph Goebbels, which strongly influenced most of German society. The Germans were pleased with Hitler's policies. They expressed the belief that soon Upper Silesia would be German. The mood of expectation and excitement of the German minority due to the entry of the Wehrmacht troops into Poland was exacerbated by the German intelligence services (APK, PWŚ, sygn. 176, Pismo Miej. Kom. PWŚ w Chorzowie, dot. nastrojów ludności na Śląsku w związku z wydarzeniami w Czechosłowacji, z 24 III 1939 r., k. 1-2). During this period, Polish security authorities organized numerous operations to combat German intelligence and diversionary networks. Preparations for armed diversion were revealed in the Silesian Voivodeship (Chinciński, 2010). Diversionary cells equipped with weapons, ammunition, explosives and radiostations have been neutralized. In the activities of the $\mathrm{V}$ column in Upper Silesia, the JDP and VB were led, who were ordered to provoke incidents with the Polish population, which was to justify German aggression against Poland (Ćwięk, 1999). German magazines such as the Kattowitzer Zeitung, Der Oberschlesische Kurier, Schlesische Zeitung and others have become propaganda tubes of the Third Reich. News of the alleged wrongs and persecution suffered by Germans by Poles was exposed. In the minority press, you could also read about the exceptionally peaceful foreign policy of the Third Reich (Cygański, 1972).

A few months before the outbreak of World War II, the activities of the V column intensified. In April 1939 Abwehrstelle-Schlesien joined the organisation of battle groups Kampf-Organisationen. They were intended to protect upper Silesian industrial plants from destruction, so that they could work for the needs of the military without much disturbance. These groups were formed by activists of Nazi parties, under the command of agents of German services, transferred from the Third Reich. The Wrocław Abwehr facility also formed organizations whose aim was to carry out subversive and sabotage operations in the last days before the outbreak of the war. They were called Sabotage-Organisationen. In May 1939, almost 2,500 people were among them, and two months later the number of diversionaries and saboteurs increased to almost 4,500 (Ćwięk, 1999). In May and June, the $\mathrm{V}$ Column in the Silesian Voivodeship completed preparations for espionage and diversionary operations in August 1939. Provocative actions against the German minority were planned in order to provide further arguments justifying the entry of the Wehrmacht troops into Poland (Cygański, 1972).

In mid-May 1939, security authorities in the Silesian voivodeship obtained information about the bombings on public buildings prepared by German intelligence. In view of the real threat, security procedures were implemented at the beginning of June 1939. The number of police patrols at public buildings and public facilities has been increased to protect them. Staff were ordered to pay attention to suspects hanging around the property, but also to official affairs incoming. All alarming signals were to be immediately reported to security authorities, in particular the counterintelligence services and the police (APK, 
PWŚ, sygn. 520, Pismo Urzędu Śledczego GK PWŚ w Katowicach, dot. sygnałów o zamachach bombowych, z 7 VI 1939 r., k. 86).

On June 20, 1939, the voivode Grażyński met with Wiesner and admonished him that the further enemy activities of the Germans would have serious consequences. Soon Wiesner, along with other Nazis, was arrested by the police. In this case, minister Józef Beck intervened, forcing the governor to release most of the diversionists and Nazis arrested in the Silesian voivodeship. Among them was Wiesner, who fled to the Free City of Gdańsk on 21 August 1939. Otto Ulitz left Poland on 19 August this year. On 29th August the Silesian Voivode appointed the Civic Guard, whose task was to prepare civil defense in the province. However, no action could save Polish Upper Silesia from the encroaching branches of the Wehrmacht (Łączewski, 2000). The German army was assisted by local people of German origin.

\section{CONCLUSIONS}

The interwar period was a time of increasing danger. The Germans did not come to terms with the loss of part of Upper Silesia. The consequences of losing World War I have resulted in a desire to retaliate in the western neighbour's mentality. The aim of lifting the treaty's restrictions on The Treaty of Versailles has become a priority objective of German policy. The resurgent forces of the Third Reich have created a serious threat to Poland's security. The increase in aggressive preparations of the Western neighbour marked a new quality of Polish-German relations.

In the run-up to the outbreak of the war in 1939, German military intelligence focused on recognizing Poland's defence capabilities. Abwehr agents often recruited from among Polish citizens of German nationality. They were commissioned in addition to intelligence tasks, organizing diversion and sabotage. Between 1935 and 1938, counter-intelligence authorities revealed about 300 cases of espionage in favour of Nazi Germany. The scale of espionage has increased significantly over the years. Most of the detected crimes took place in the last years of interwar Poland.

The politician, led over thirteen years, has made a major contribution to strengthening polish national and state consciousness among the people of Upper Silesia. The voivode correctly assessed the anti-Polish nature of German actions, which were particularly strong in the years 1933-1939.

\section{REFERENCES}

Ajnenkiel, A. (1980) Polska po przewrocie majowym. Zarys dziejów politycznych Polski 1926-1939, Warszawa: Wydawnictwo Wiedza Powszechna.

APK, PWŚ, sygn. 196, Pismo Miej. i Pow. Kom. PWŚ do kierowników Komisariatów i Posterunków PWŚ powiatu katowickiego, dot. szkół niemieckich, z 12 VI 1926 r., k. 1

APK, PWŚ, sygn. 130, Sprawozdanie miesięczne ze stycznia 1927 r., z 8 II 1927 r., k. 34.

APK, PWŚ, sygn. 243, Pismo 23 Dywizji Piechoty do Śląskiego Urzędu Policji Politycznej w Katowicach, z 26 V 1925 r., k. 7.

APK, PWŚ, sygn. 243, Pismo Miej. i Pow. Kom. PWŚ do Śląskiego Urzędu Policji Politycznej w Katowicach, z 11 VII 1925 r., k. 9.

APK, PWŚ sygn. 215, Wycinek z prasy, br., k. 222.

APK, PWŚ, sygn. 215, Pismo Pow. Kom. PWŚ w Tarnowskich Górach do GK PWŚ w Katowicach, z 1VI 1927 r., k. 223. 
APK, PWŚ, sygn. 247, „Polska Zachodnia” z 3 IV 1931 r., k. 171.

APK, PWŚ, sygn. 202, Raport przygotowany dla Departamentu I Politycznego MSW w Warszawie, dot. ruchu hitlerowskiego w województwie śląskim, z 1 XII 1932 r., k. 105-108.

APK, PWŚ, sygn. 209, Doniesienie w sprawie członków „Jungdeutsche Partei” i „Deutsche Arbeiterpartei”, z 1932 r., k. 3.

APK, PWŚ, sygn. 212, Pismo Wydziału Śledczego Miej. i Pow. Kom. PWŚ w Katowicach do Prokuratury Sądu Okręgowego w Katowicach, z 11 VII 1936 r., k. 236-237.

APK, PWŚ, sygn. 207, Pismo Miej. Kom. PWŚ w Chorzowie do GK PWŚ w Katowicach, z 18 III 1936 r., k. 180-183.

APK, PWŚ, sygn. 406, Orzeczenie Ekspozytury nr IV Oddziału II SG w Katowicach, z 21 VI 1939 r., k. 9-10.

APK, PWŚ, sygn. 388, Opinia Miej. Kom. PWŚ w Chorzowie o członkach zarządu GDA, z 14 III 1939 r. k. 247-248.

APK, PWŚ, sygn. 172, Pismo Pow. Kom. PWŚ w Lublińcu do GK PWŚ w Katowicach, dot. wywiadu granicznego, z 9 IV 1937 r., k. 417.

APK, PWŚ, sygn. 2, Rozkaz nr 230, GK PWŚ w Katowicach, z 23 XII 1925 r., k. 377.

APK, PWŚ, sygn. 237, Pismo Ekspozytury nr 4 Oddziału II SG w Krakowie do Śląskiego Urzędu Policji Politycznej w Katowicach, z 25 VII 1927 r., k. 841.

APK, PWŚ, sygn. 237, Pismo Kierownika Posterunku Oficerskiego nr 2 w Katowicach, dot. szpiegostwa niemieckiego, z 1 VIII 1927 r., k. 842.

APK, PWŚ, sygn. 237, Pismo MWS do wojewodów, dot. utworzenia Polskiej Agencji Informacji Handlowej, z 23 II 1932 r., k. 374.

APK, PWŚ, sygn. 176, Pismo Miej. Kom. PWŚ w Chorzowie, dot. nastrojów ludności na Śląsku w związku z wydarzeniami w Czechosłowacji, z 24 III 1939 r., k. 1-2.

APK, PWŚ, sygn. 520, Pismo Urzędu Śledczego GK PWŚ w Katowicach, dot. sygnałów o zamachach bombowych, z 7 VI 1939 r., k. 86.

Chinciński, T. (2010). Fortpoczta Hitlera. Niemiecka dywersja w Polsce w 1939 roku. Gdańsk-Warszawa: Wydawnictwo Naukowe SCHOLAR.

Cygański, M. (1972) Hitlerowska V kolumna w województwie śląskim i krakowskim w 1939 roku. Opole: Wydawnictwo Instytutu Śląskiego w Opolu.

Ćwięk, H. (1999). Obrona Śląska przed wptywami wywiadu niemieckiego w latach 1933-1939. Katowice: Wydawnictwo Naukowe „Śląsk”.

— (2006). O niektórych aspektach bezpieczeństwa na obszarze województwa ślaskiego w latach dwudziestych. „Res Politicae”, red. H. Ćwięk, t. I.

- (2001). Przeciw Abwehrze. Warszawa: Bellona.

(2009). W tajnej stużbie II Rzeczypospolitej. Wywiad Polski wobec Niemiec w latach 1918-1939. Częstochowa: Wydawnictwo Akademii im. Jana Długosza w Częstochowie.

- (1998), Zwalczanie niemieckich stużb specjalnych na ziemiach zachodnich i pótnocnych II Rzeczypospolitej. Warszawa: Urząd Ochrony Państwa.

Długajczyk, E. (1986). Panorama polityczna województwa śląskiego 1922-1939. Katowice: Muzeum Śląskie.

- (2007). Zestawienie osób aresztowanych i zasądzonych $w$ województwie śląsim $w$ latach 1922-1939 z powodu wspótpracy z wywiadem niemieckim. „Szkice Archiwalno-Historyczne”, $\mathrm{nr} 3$. 
Drozdowski, M.M. (1991). Śląsk i Zagtębie Dąbrowskie w myśli politycznej Józefa Pitsudskiego. „Niepodlegtość i Pamięć”, nr 4/8 (8).

Gerlich, M.G. (1997). Poczucie tożsamości etnicznej ludności rodzimej Górnego Śląska w XX wieku (do 1989 roku). „Niepodległość i Pamięć”, nr 4/2 (8).

IPN Ka, sygn. 063/84 t. 1, Charakterystyka kontrwywiadowcza województwa katowickiego, k. 77.

Kozaczuk, W. (1977). Bitwa o tajemnice. Stużby wywiadowcze Polski i Rzeszy Niemieckiej 1922-1939. Warszawa: Wydawnictwo Książka i Wiedza.

Łączewski, J. (2000). Michat Grażyński (1890-1965). Sylwetka polityka. Częstochowa: Wydawnictwo Wyższej Szkoły Pedagogicznej w Częstochowie.

Misiuk, A. (2016). Stużby wywiadu i kontrwywiadu II Rzeczypospolitej, Warszawa: Difin.

Nowak, K. (2014). Michat Grażyński [w:] Mokrosz, J., Węcki, M., red., Oni decydowali na Górnym Śląsu w XX wieku. Katowice-Rybnik: Archiwum Państwowe w Katowicach, Stowarzyszenie Humanistyczne Europa, Śląsk, Świat Najmniejszy.

Oświadczenie rządowe z dnia 23 maja 1922r. w sprawie podziału Górnego Śląska (Dz.U. nr 44, poz. 369).

Paruch, W. (2009). Parlament w państwie autorytarnym. Rozważania o myśli politycznej Józefa Pitsudskiego (1926-1935) [w:] Adamczyk, W.A., red., Józef Pitsudski a parlamentaryzm polski. Warszawa: Instytut Józefa Piłsudskiego; Bełchatów: Związek Strzelecki „Strzelec” Organizacja Społeczno-Wychowawcza. Jednostka Strzelecka nr 1001 im. gen. dyw. Janusza Głuchowskiego. Pepłoński, A. (2002). Kontrwywiad II Rzeczypospolitej. Warszawa: Bellona.

Pindel, K. (1998). Śląsk w systemie obronnym II Rzeczypospolitej. Warszawa: Bellona.

Potocki, S (1984). Deutsche Stiftung - tajna agenda rzadu niemieckiego $w$ okresie międzywojennym do spraw mniejszości niemieckich [w:] Czubiński, A., red., Rola mniejszości niemieckiej w rozwoju stosunków politycznych w Europie 1918-1945. Poznań: Wydawnictwo Naukowe Uniwersytetu im. Adama Mickiewicza w Poznaniu.

Sprengel, B. (2014). Aspekty procesowe ścigania szpiegostwa w przedwojennej Polsce [w:] Nawrocki, Z., red., Kontrwywiad II RP (1914) 1918-1945 (1948), t. II. Emów: Agencja Bezpieczeństwa Wewnętrznego. Centralny Ośrodek Szkolenia.

Wanatowicz, M.W. (1997). Górny Ślask i jego miejsce w Drugiej Rzeczypospolitej. „Niepodległość i Pamięć”, 4/2 (8).

Wiśniewska, M., Wyszczelski, L. (2009). Bezpieczeństwo narodowe Polski w latach 1918-1939. Torun: Dom Wydawniczy DUET.

DOI: $10.7862 /$ rz.2020.hss.46

The text was submitted to the editorial office: July 2020.

The text was accepted for publication: December 2020. 
